\title{
Uji Potensi Bakteri Endofit Kitinolitik Tanaman Padi (Oryza sativa L.) Sebagai Penghasil Hormon IAA (Indole Acetic Acid)
}

\author{
Ahmad Hanafi ${ }^{1}$, Susiana Purwantisari ${ }^{2}$ dan Budi Raharjo ${ }^{2}$ \\ ${ }^{1}$ Program Studi Biologi Departemen Biologi FSM Undip \\ ${ }^{2}$ Laboratorium Bioteknologi Departemen Biologi FSM Undip \\ Departemen Biologi Fakultas Sains dan Matematika Universitas Diponegoro \\ Semarang 50275 Tlp. (024) 7474754; Fax. (024) 76480690. \\ Email: ahmadhanafi1994@gmail.com ${ }^{1}$ \\ HP : 08974215021
}

\begin{abstract}
IAA (Indole Acetic Acid) is a hormone in plants that was role in the cleavage of roots, inhibits the growth of side shoots, stimulate cell division and the formation of xylem and phloem tissue. This study aimed to test the potential of endophytic bacteria chitinolytic rice crop as hormone-producing IAA. This study uses 9 isolates of endophytic bacteria chitinolytic rice plants in isolation during practical work. The experiment consisted of 15 treatments and 3 replications. This study uses a randomized block design. The treatments tryptophan concentration combined with a variation $\mathrm{pH}$, the endophytic bacteria grown on media chitinolytic tryptophan concentration of 0 $\mathrm{mg} / \mathrm{L}, 102 \mathrm{mg} / \mathrm{L}, 204 \mathrm{mg} / \mathrm{L}, 306 \mathrm{mg} / \mathrm{L}$ and $408 \mathrm{mg} / \mathrm{L}$ are combined with $\mathrm{pH}$ 5, 7 and 9. the treatment was observed for 48 hours and observation once every 3 hours. The measured variable is the result of the production of IAA hormone with the treatment combination of tryptophan with pH. IAA hormone outcome data were analyzed using Analysis of Variance Univariates at level of 95\%. IAA hormone qualitative test results showed positive results in bacterial isolates KA12, KA11 and KB24. IAA hormone quantitative results of bacterial isolates producing IAA hormone KA12 high of 2,03 mg/L in the combination treatment of tryptophan $408 \mathrm{mg} / \mathrm{L}$ at $\mathrm{pH} 7$ at 24 hours incubation. KA12 bacterial isolates are endophytic bacteria chitinolytic potential to produce hormones IAA, yet the results of data analysis showed that each treatment combination with $\mathrm{pH}$ tryptophan to IAA production were not significantly different.
\end{abstract}

Keywords: hormone IAA, chitinolytic endophytic bacteria, tryptophan, pH

\begin{abstract}
Abstrak
IAA (Indole Acetic Acid) adalah hormon pada tanaman yang berperan dalam pembelahan akar, menghambat pertumbuhan tunas samping, merangsang pembelahan sel dan pembentukan jaringan xylem dan floem. Penelitian ini bertujuan untuk menguji potensi bakteri endofit kitinolitik tanaman padi sebagai penghasil hormon IAA. Penelitian ini menggunakan 9 isolat bakteri endofit kitinolitik tanaman padi yang di isolasi pada saat kerja praktik. Penelitian terdiri dari 15 perlakuan dan 3 ulangan. Penelitian ini menggunakan Rancangan Acak Kelompok. Perlakuan konsentrasi triptofan dengan variasi $\mathrm{pH}$, yaitu bakteri endofit kitinolitik ditumbuhkan pada media konsentrasi triptofan $0 \mathrm{mg} / \mathrm{L}, 102 \mathrm{mg} / \mathrm{L}, 204 \mathrm{mg} / \mathrm{L}, 306 \mathrm{mg} / \mathrm{L}$ dan $408 \mathrm{mg} / \mathrm{L}$ dan dikombinasi dengan pH 5, 7, dan pH 9. Perlakuan diamati selama 48 jam dan pengamatan setiap 3 jam sekali. Variabel yang diukur adalah hasil produksi IAA dengan perlakuan kombinasi triptofan dengan $\mathrm{pH}$. Data hasil hormon IAA yang diperoleh kemudian dianalisis menggunakan Univariates Analysis of Variance pada taraf kepercayaan 95\%. Hasil kualitatif hormon IAA menunjukan hasil positif pada isolat bakteri KA12, KA11 dan KB24. Hasil kuantitatif hormon IAA isolat bakteri KA12 memproduksi IAA tertinggi sebesar 2,03 mg/L pada perlakuan kombinasi triptofan $408 \mathrm{mg} / \mathrm{L} \mathrm{dengan} \mathrm{pH} 7$ pada inkubasi 24 jam. Isolat bakteri KA12 adalah bakteri endofit kitinolitik yang berpotensi dalam menghasilkan hormon IAA, namum hasil analisis data menunjukan bahwa masing-masing perlakuan kombinasi triptofan dengan pH terhadap produksi hormon IAA tidak berbeda nyata.
\end{abstract}

Kata kunci: hormon IAA, bakteri endofit kitinolitik, triptofan, $\mathrm{pH}$. 


\section{PENDAHULUAN}

Kebutuhan beras secara nasional mengalami beberapa masalah serius, salah satunya adalah menurunnya produksi tanaman padi. Menurunnya produksi tanaman padi disebabkan oleh faktor abiotik (iklim) maupun biotik oleh mikroba patogen. Patogen yang sering menyebabkan penyakit tanaman padi diantaranya adalah jamur Rhizoctonia solani (Rs) penyebab penyakit hawar pelepah daun (HPD) dan Pyricularia oryzae (Po) penyebab penyakit blas. Biasanya petani menggunakan bahan kimia seperti pupuk sintetis, fungisida dan pestisida untuk tujuan meningkatkan hasil panen dan pengendalian hama serta penyakit tanaman.

Beberapa cara telah ditempuh untuk mengatasi permasalahan tersebut seperti penggunaan pupuk dan pestisida kimia. Penggunaan pupuk dan pestisida kimia secara berlebihan akan memberikan dampak negatif bagi lingkungan maupun manusia. Semakin tingginya kesadaran masyarakat terhadap bahaya fungisida dan daya beli yang terus meningkat terhadap bahan pangan, menyebabkan perlunya penggunaan agen hayati sebagai alternatif pengganti pupuk dan pestisida kimia. Salah satu alternatif tersebut adalah dengan menggunakan mikroorganisme endofit. Simanjuntak et al. (2002), melaporkan mikroorganisme endofit mempunyai potensi yang dapat dimanfaatkan sebagai penghasil metabolit sekunder seperti yang terkandung di dalam tanaman inangnya.

Mikroba endofit dapat menjadi sumber berbagai metabolit sekunder yang berpotensi untuk dikembangkan dalam bidang medis, pertanian dan industri. Mikroba endofit dapat diisolasi dari beberapa tanaman vascular salah satunya adalah tanaman padi (Oryza sativa L.) yang digunakan sebagai tanaman pertanian di Indonesia. Padi merupakan tanaman turun temurun yang diwariskan oleh nenek moyang dan menjadi makanan pokok masyarakat Indonesia. Mano et al. (2007), telah mengisolasi mikroba endofit yaitu bakteri endofit dari tanaman padi diantaranya Bacillus, Curtobacterium, Methylobacterium, Sphingomonas, Pantoea, Bacillus, Brevibacillus, Mycobacterium, Enterobacter, Chryseobacterium.
Terdapat sembilan isolat bakteri endofit yang berhasil diisolasi dari bagian dalam jaringan batang, akar dan daun tanaman padi yang diperoleh dari persawahan padi Sigar Bencah pada saat kerja praktik. Sembilan isolat bakteri endofit tersebut dapat menghasilkan kitinase yang sudah diuji aktivitas kitinolitiknya. Kitinase dapat dihasilkan oleh kelompok bakteri dan jamur antagonis. Giyanto et al. (2010), melaporkan beberapa bakteri yang menghasilkan kitinase adalah Pseudomonas fluoresens dan Bacillus sp. yang bersifat antagonis terhadap jamur Rhizoctania solani, Fusarium oxysporum, Helminthosporium maydis, dan Pyricularia oryzae.

Bakteri endofit selain kitinolitik ada beberapa bakteri endofit diketahui dapat menghasilkan hormon IAA (Indole Acetic Acid). Hormon IAA adalah salah satu jenis hormon yang dapat memacu pertumbuhan tanaman. Menurut Tarabily et al. (2003), hormon IAA adalah hormon endogen tanaman yang disentesis dalam batang, akar dan daun dengan meningkatkan proses elongasi sel dan perpanjangan batang seperti halnya differensiasi sel. Munif et al. (2012), melaporkan bahwa sejumlah mikroba hasil isolasi tanaman padi dapat memacu pertumbuhan tanaman padi dan mempunyai kemampuan aktivitas kitinolitik terhadap cendawan patogen Rhizoctania solani dan Pyricularia grisea. Adanya kemampuan bakteri dalam menghasilkan enzim kitinase dan hormon IAA dapat membantu pertumbuhan tanaman serta melindungi tanaman dari patogen yang menyebabkan penyakit tanaman. Berdasarkan uraian diatas maka perlu dilakukan penelitian tentang uji potensi bakteri endofit penghasil kitinase oleh bakteri kitinolitik serta penghasil hormon IAA pada tanaman padi agar dapat mengurangi penggunaan pupuk sintetis serta pestisida kimia yang dapat menyebabkan kerusakan pada lingkungan

\section{BAHAN DAN METODE Waktu dan Tempat Penelitian}

Penelitian dilaksanakan pada bulan Maret Oktober 2016 di Laboratorium Bioteknologi, 
Departemen Biologi, Fakultas Sains dan Matematika, Universitas Diponegoro.

\section{Alat dan Bahan}

Alat yang digunakan adalah autoklaf, centrifuge, cawan Petri, spektrofotometer, gelas benda, gelas penutup, oven, tabung reaksi, rotary shaker, jarum ose, pipet ukur, pipet tetes, vortex, ose bulat, mikroskop, erlenmeyer, laminary air flow (LAF), lampu Bunsen, milipore filter, dan $\mathrm{pH}$ meter. Bahan yang digunakan adalah 9 kultur isolat bakteri endofit kitinolitik tanaman padi, alkohol $70 \%$, medium Nutrient Agar (NA), Nutrient Broth (NB), $\mathrm{H}_{2} \mathrm{O}_{2}, \mathrm{NaOH} 1 \mathrm{~N}, \mathrm{HCL} 1 \mathrm{~N}$, Agar, reagen Salkowsky, aquades, larutan Gram A (larutan Hucker's Crystal Violet), larutan Gram B (mordan JKJ), larutan Gram C (alkohol-aseton), larutan Gram D (safranin), minyak imersi, triptofan, koloid kitin, dan media kitin (0,1 \% $\mathrm{MgSO}_{4} \cdot 7 \mathrm{H}_{2} \mathrm{O}, 0,02 \% \mathrm{~K}_{2} \mathrm{HPO}_{4}, 0,1 \%$ ekstrak yeast, dan $1,5 \%$ agar).

\section{Prosedur Penelitian Peremajaan Isolat}

Peremajaan isolat bakteri dilakukan dengan mengambil 1 ose bakteri endofit kitinolitik hasil isolasi dari tanaman padi kemudian digoreskan pada medium NA miring dan medium kitin miring, kemudian diinkubasi selama 24 jam pada suhu ruang.

\section{Aktivitas Kitinolitik (Pujiyanto et al., 2008)}

Seleksi 9 isolat bakteri kitinolitik diuji kembali aktivitas kitinolitiknya dengan cara menumbuhkan kembali secara serentak semua isolat dengan cara ditotolkan pada media agar kitin dan diinkubasi selama 48 - 72 jam. Koloni bakteri yang tumbuh dan membentuk zona bening (clear zone) ditentukan indeks kitinolitiknya. Sembilan isolat yang memiliki nilai indeks kitinolitik tertinggi ditetapkan sebagai isolat terpilih untuk diuji kemampuannya dalam menghasilkan hormon IAA.

Analisis Kualitatif Hormon IAA (Gravel, 2007)

Isolat bakteri ditumbuhkan pada medium NA dengan penambahan triptofan $100 \mathrm{mg} / \mathrm{L}$ dan medium NA tanpa triptofan, kemudian diuji dengan cara ditetesi larutan reagen Salkowsky.
Hasil positif setelah ditetesi larutan reagen Salkowsky ditunjukkan dengan terjadinya perubahan warna menjadi merah muda setelah diinkubasi di tempat gelap selama 30 menit.

\section{Analisis Kuantitatif Hormon IAA (Patten dan Glick, 2002)}

sebanyak $1 \mathrm{~mL}$ IAA yang terlarut dalam methanol dari hasil ekstraksi masing-masing perlakuan, dicampur dengan $4 \mathrm{~mL}$ reagen Salkwosky, didiamkan pada suhu ruang dalam waktu 30 menit dan diukur absorbansinya dengan panjang gelombang $535 \mathrm{~nm}$. Konsentrasi hormon IAA pada setiap perlakuan ditentukan dengan menggunakan kurva standar.

\section{Pembuatan Kurva Standar Hormon IAA (Sinta, 2008).}

Hormon IAA sintetik sebanyak $2 \mathrm{mg}$ dilarutkan ke dalam $20 \mathrm{~mL}$ methanol, selanjutnya diambil $1 \mathrm{~mL}$ untuk diukur absorbansi menggunakan spektrofotometer dengan panjang gelombang $535 \mathrm{~nm}$, dengan penambahan $4 \mathrm{~mL}$ reagen Salkowsky. Sebanyak $5 \mathrm{~mL}$ hormon IAA sintetik dalam metanol, diencerkan dengan penambahan $5 \mathrm{~mL}$ methanol. Larutan hormon IAA sintetik yang telah diencerkan, diencerkan kembali secara bertahap dengan perbandingan $1: 1$ dan diukur absorbansinya.

\section{Pewarnaan Gram (Ferdiaz, 1993)}

Preparat apus bakteri dibuat dengan cara mengambil satu ose biak bakteri dari medium NA, kemudian dibuat apus setipis mungkin, dikeringkan, dan difiksasi di atas lampu Bunsen. Preparat apus ditetesi pewarna pertama dengan larutan Gram A selama 1 menit, warna dibuang, ditetesi larutan Gram B selama 1 menit, kemudian preparat apus dilunturkan dengan larutan Gram C selama 30 menit. Selanjutnya alkohol dibuang, preparat dicuci dengan aquades dan diberi pewarna kedua dengan larutan Gram D selama 2 menit. Warna kemudian dibuang dan dibersihkan dengan aquades, dikeringkan dan diamati morfologi sel, serta warnanya di bawah mikroskop.

\section{Uji Motilitas (Anggara, 2014)}

Isolat ditanam dengan ose lancip yang ditusukan ke dalam medium semi solid. Sehingga 
apabila bakterinya merupakan bakteri non motil maka akan terlihat 1 garis. Uji dikatakan positif motil apabila isolat yang ada dalam medium menyebar dan tercampur dengan medium.

\section{Uji Katalase (Hadioetomo, 1990)}

Uji Katalase dilakukan dengan meneteskan hidrogen peroksida $\left(\mathrm{H}_{2} \mathrm{O}_{2}\right) 3 \%$ pada gelas obyek yang bersih. Biakan dioleskan pada gelas obyek yang sudah ditetesi hidrogen peroksida dengan ose. Suspensi dicampur secara perlahan menggunakan ose, hasil yang positif ditandai oleh terbentuknya gelembung-gelembung udara.

\section{Ekstraksi Hormon IAA (Frankenberger \& Poth , 1987)}

Biakan bakteri pengasil hormon IAA diambil $10 \mathrm{~mL}$ supernatan kemudian diasamkan sampai $\mathrm{pH}$ 3 dengan penambahan HCL $1 \mathrm{~N}$ dan ditambah etil asetat. Supernatan divortex dan terbentuk 2 lapisan yaitu lapisan atas dan lapisan bawah. Lapisan bawah adalah organik, sedangkan lapisan atas adalah etil asetat. Lapisan atas dipisahkan kemudian diletakan di botol gelap lalu diuapkan sampai habis. Hasilnya IAA menempel pada botol kemudian dilarutkan $5 \mathrm{~mL}$ methanol.

\section{Rancangan Percobaan}

Penelitian ini menggunakan Rancangan Acak Kelompok (RAK) faktorial (5 x 3) dengan 3 kali ulangan. Faktor pertama menggunakan $\mathrm{pH} 5$, $\mathrm{pH} 7$ dan $\mathrm{pH}$ 9. Faktor kedua menggunakan konsentrasi triptofan $0 \mathrm{mg} / \mathrm{L}, 102 \mathrm{mg} / \mathrm{L}, 204 \mathrm{mg} / \mathrm{L}$, $306 \mathrm{mg} / \mathrm{L}$ dan $408 \mathrm{mg} / \mathrm{L}$.

\section{Analisis Data}

Data berupa hasil hormon IAA dianalisis menggunakan Univariates Analysis of Variance pada taraf kepercayaan 95\% untuk pembuktian hasil berpengaruh nyata atau tidak. Jika terdapat beda nyata dilanjutkan dengan uji lanjut Duncan's Multiple Range Test (DMRT). Perhitungan dilakukan menggunakan perangkat lunak program SPSS versi 16.0..

\section{HASIL DAN PEMBAHASAN}

Perhitungan indeks aktivitas kitinolitik masing-masing isolat bakteri dapat dilihat pada Tabel 1.
Tabel 1. Perhitungan Indeks Aktivitas Kitinolitik

\begin{tabular}{ccccc}
\hline No & $\begin{array}{c}\text { Kode } \\
\text { Isolat }\end{array}$ & $\begin{array}{c}\text { Diameter } \\
\text { Daerah } \\
\text { Bening } \\
(\mathrm{cm})\end{array}$ & $\begin{array}{c}\text { Diameter } \\
\text { Koloni } \\
(\mathrm{cm})\end{array}$ & $\begin{array}{c}\text { Indeks } \\
\text { Aktivitas } \\
\text { kitinolitik }\end{array}$ \\
\hline 1 & KB11 & 2,2 & 1,8 & 1,22 \\
2 & KB12 & 1 & 0,9 & 1,1 \\
3 & KB13 & 0 & 0 & 0 \\
4 & KB21 & 1,3 & 1,2 & 1,08 \\
5 & KB22 & 1,1 & 1 & 1,1 \\
6 & KB23 & 1,1 & 1 & 1,1 \\
7 & KB24 & 2,5 & 1,2 & 2,08 \\
8 & KA11 & 2,3 & 1,8 & 1,27 \\
9 & KA12 & 1,5 & 0,9 & 1,66 \\
\hline
\end{tabular}

Terdapat 3 isolat bakteri kitinolitik yang paling besar indeks akitivitas kitinolitiknya dari 9 isolat bakteri kitinolitik. Tiga isolat bakteri tersebut adalah isolat bakteri KB24 menghasilkan indeks aktivitas kitinolitik paling tinggi sebesar 2,08, selanjutnya diikuti oleh isolat bakteri KA11 menghasilkan indeks aktivitas kitinolitik sebesar 1,27 dan isolat bakteri KA12 menghasilkan indeks aktivitas kitinolitik sebesar 1,66. Menurut Patil (2000), Besarnya zona bening yang dihasilkan tergantung jumlah monomer N-asetilglukosamin, semakin besar jumlah $\mathrm{N}$-asetilglukosamin yang dihasilkan maka akan semakin besar zona bening yang terbentuk disekitar koloni. Isolat bakteri KA11, KA12 dan KB24 yang menghasilkan indeks aktivitas kitinolitik paling besar dibandingkan isolat bakteri yang lain, selanjutnya isolat bakteri tersebut diuji hormon IAA secara kualitatif.

Isolat bakteri KA12 yang ditumbuhkan pada medium NA dengan penambahan triptofan 100 mg/L setelah ditetesi reagen Salkowsky koloni berwarna merah muda. Menurut Sukmadewi (2015), bakteri yang mampu menghasilkan hormon IAA akan berwarna merah saat ditetesi reagen Salkowsky, karena adanya interaksi antara IAA dan Fe membentuk senyawa kompleks $\left[\mathrm{Fe}_{2}(\mathrm{OH})_{2}(\mathrm{IA})_{4}\right]$. Isolat bakteri KA12 warna merah muda lebih pekat dibandingkan dengan warna merah muda pada isolat bakteri KA11 dan KB24 (Gambar 1.). 

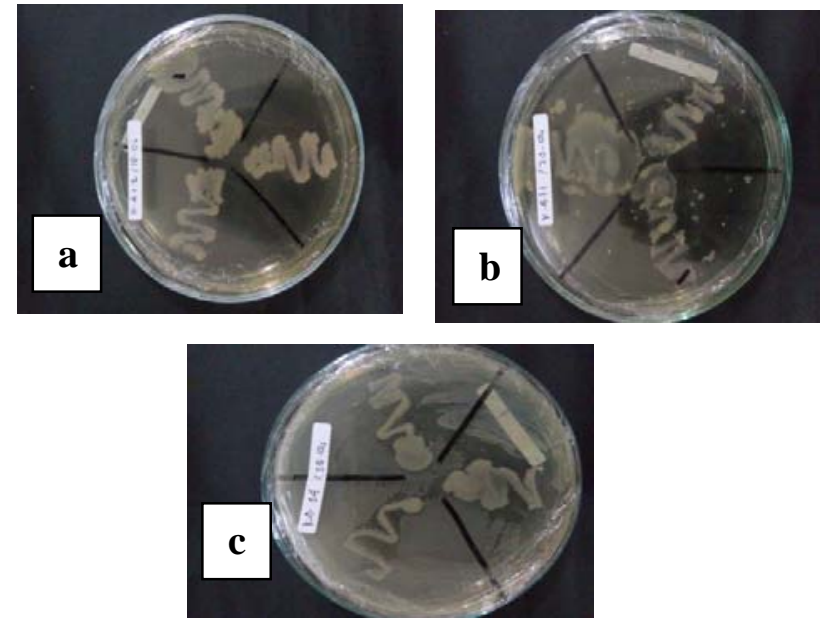

Gambar 1. a. isolat bakteri KA12, b. isolat bakteri KA11 dan c. isolat bakteri KB24 yang diinkubasi 30 menit setelah ditetesi reagen Salkowsky.

Isolat bakteri KA11, KA12 dan KB24 selanjutnya dilakukan pengecatan Gram, uji katalase dan uji motil. Berdasarkan pengecatan Gram isolat bakteri KA12, KA11 dan KB24 adalah Gram negatif berwarna merah dan berbentuk basil. Cooper (2007) menyatakan bahwa bakteri Gram negatif memiliki sistem membran ganda dimana membran plasmanya diselimuti oleh membran luar permeabel. Lay (1994) melaporkan bahwa bakteri Gram negatif berwarna merah karena pewarna kristal violet larut pada saat pemberian larutan aseton alkohol sehingga mengambil warna merah safranin. Karakter bakteri pada isolat bakteri KA11, KA12 dan KB24 dapat dilihat pada Tabel 2 .

Tabel 2. Karakter isolat bakteri KA11, KA12 dan KB24

\begin{tabular}{|c|c|c|c|c|c|c|}
\hline Isolat & $\begin{array}{l}\text { Warna } \\
\text { Koloni }\end{array}$ & Form & Elevasi & Margin & Tekstur & $\begin{array}{c}\text { Bentuk } \\
\text { Sel }\end{array}$ \\
\hline KA11 & $\begin{array}{c}\text { Putih } \\
\text { Susu }\end{array}$ & Irregular & Convex & Rhizoid & Basah & Basil \\
\hline KA12 & $\begin{array}{l}\text { Putih } \\
\text { Susu }\end{array}$ & Irregular & Convex & Rhizoid & Basah & Basil \\
\hline KB24 & $\begin{array}{l}\text { Putih } \\
\text { Susu }\end{array}$ & Irregular & Flat & Rhizoid & Kering & Basil \\
\hline
\end{tabular}

Uji katalase pada isolat bakteri KA11, KA12, KB24 menunjukan adanya gelembunggelembung udara. Katalase merupakan enzim yang mengkatalisa penguraian hidrogen peroksida menjadi $\mathrm{H}_{2} \mathrm{O}$ dan $\mathrm{O}_{2}$, hidrogen peroksida bersifat toksik terhadap sel karena bahan ini menginaktifkan enzim dalam sel. Uji motilitas pada isolat bakteri KA11, KA12 dan KB24 menunjukan bakteri motil, dimana bakteri tersebut tumbuh menyebar dimedium NB semi solid. Bakteri motil disebabkan adanya flagel yang berfungsi sebagai alat gerak bakteri.

Isolat bakteri KA12 mampu menghasilkan hormon IAA yang tinggi dibandingkan isolat bakteri KA11 dan KB24, kemudian dilanjutkan dengan pengujian hormon IAA secara kuantitatif. Pengujian yang dilakukan adalah isolat bakteri KA12 ditumbuhkan pada medium NB dengan kombinasi $\mathrm{pH}$ dengan konsentrasi triptofan. Produksi hormon IAA dilihat pada jam $\mathrm{T}_{24}$ (inkubasi 24 jam) dan $\mathrm{T}_{48}$ (inkubasi 48 jam), karena pada jam tersebut menunjukan produksi hormon IAA yang optimum. Kresnawaty (2008) melaporkan bahwa produksi hormon IAA rendah pada inkubasi 24 jam, sedangkan produksi hormon IAA paling tinggi pada inkubasi 48 jam. Penelitian Khaerani (2009), melaporkan bahwa isolat bakteri endofit jagung $\mathrm{KB}_{3}$ menghasilkan hormon IAA sebesar 1,125 mg/L pada hari ke-2 atau inkubasi 48 jam.

Berdasarkan Univariates Analysis of Variance menunjukan tidak ada perbedaan nyata pada kombinasi antara $\mathrm{pH}$ dengan triptofan terhadap produksi hormon IAA pada inkubasi jam $\mathrm{T}_{24}$ dan $\mathrm{T}_{48}$ (Sig $\left.>0,05\right)$. Bahwa produksi hormon IAA paling tinggi pada perlakuan kombinasi triptofan $408 \mathrm{mg} / \mathrm{L}$ dan $\mathrm{pH} 7\left(\mathrm{D}_{5} \mathrm{P}_{2}\right)$ pada inkubasi $\mathrm{T}_{24}$ dan $\mathrm{T}_{48}$, tetapi tidak berbeda nyata dengan perlakuan kombinasi triptofan $408 \mathrm{mg} / \mathrm{L}$ dengan pH 5 dan 408 mg/L dengan pH 9 (Gambar 2.), diikuti perlakuan kombinasi triptofan $0 \mathrm{mg} / \mathrm{L}, 102$ mg/L, 204 mg/L dan 306 mg/L dengan $\mathrm{pH}$ 5, 7, dan $\mathrm{pH} 9$. 


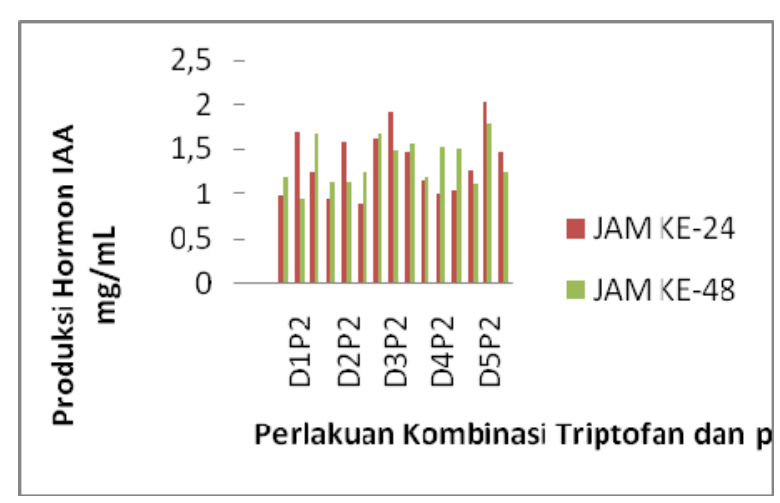

Gambar 2. Produksi hormon IAA isolat bakteri KA12 dengan perlakuan kombinasi triptofan dengan $\mathrm{pH}$ pada masa inkubasi 24 jam dan 48 jam.

Isolat bakteri KA12 memproduksi hormon IAA paling besar 2,03 $\mathrm{mg} / \mathrm{L}$ pada perlakuan kombinasi triptofan $408 \mathrm{mg} / \mathrm{L}$ dengan $\mathrm{pH} 7\left(\mathrm{D}_{5} \mathrm{P}_{2}\right)$ pada inkubasi $\mathrm{T}_{24}$. Inkubasi $\mathrm{T}_{48}$ memproduksi hormon IAA sebesar $1,78 \mathrm{mg} / \mathrm{L}$ pada perlakuan kombinasi triptofan $408 \mathrm{mg} / \mathrm{L}$ dengan $\mathrm{pH} 7\left(\mathrm{D}_{5} \mathrm{P}_{2}\right)$. Menurut Lestari et al. (2007), bahwa pada awal inkubasi sumber nutrisi tinggi sehingga produksi hormon IAA tinggi dan terus meningkat setelah itu produksi hormon IAA turun sampai akhir inkubasi karena mengurangnya nutrisi media.

\section{KESIMPULAN}

Isolat bakteri KA12 adalah bakteri endofit kitinolitik yang berpotensi dalam menghasilkan hormon IAA dibandingkan dengan isolat KA11 dan KB24. Isolat bakteri KA12 memproduksi hormon IAA paling tinggi sebesar 2,03 mg/L yang ditumbuhkan pada medium perlakuan kombinasi triptofan $408 \mathrm{mg} / \mathrm{L}$ dengan pH 7 pada inkubasi 24 jam, namum hasil analisis data menunjukan bahwa masing-masing perlakuan kombinasi triptofan dengan $\mathrm{pH}$ terhadap produksi hormon IAA tidak berbeda nyata.

\section{UCAPAN TERIMAKASIH}

Penulis berterima kasih kepada Bapak dan Ibu dosen serta seluruh staff laboratorium dan perpustakan Departemen Biologi Fakultas Sains dan Matematika atas bimbingan dan pengarahan, kedua orang tua penulis dan seluruh rekan penulis yang tidak dapat disebutkan satu-persatu.

\section{DAFTAR PUSTAKA}

Anggara, B. S., Yuliana dan L. Lisdiana. 2014. Isolasi dan Karakterisasi Bakteri Endofit Penghasil Hormon Indole Acetic Acid dari Akar Tanaman Ubi Jalar. J lenteraBio 3(3): 160-167.

Cooper, G.M dan R. E. Hausman. 2007. The Cell: A Molecular Approach. $4^{\text {th }}$ ed. Sinauer Associates, Inc., Sunderland.

Fardiaz, S. (1993) Analisis Mikrobiologi Pangan. PT Prasindo Persada. Jakarta.

Frankenberger, W.T. and M. Poth. 1987. Biosynthesis of indole-3-acetic acid by the pine ectomycorrhizal fungus Pisolithus tinctorius. Appl Environt. Microbiol. 53(12): 2908-2913.

Gravel, V., H. Antoun., J. Russel., Tweddel. 2007. Effect indole-acetic acid (IAA) o the development of symptoms caused Pythium ultimum on tomato plant. Eur J Plant Pathol 119(10):457-462.

Hadioetomo, R. S. 1990. Mikrobiologi Dasar dalam Praktek Teknik dan Prosedur Dasar Laboratorium. Gramedia: Jakarta.

Khairani, G. 2010. Isolasi Dan Uji Kemampuan Bakteri Endofit Penghasil Hormon IAA (Indole Acetic Acid) Dari Akar Tanaman Jagung (Zea mays L.). Skripsi. Dept. Biologi Fakultas Sains Dan Ilmu Pengetahuan Alam. Univ. Sumatera Utara, Medan.

Kismiyati, Sri., W. N. Yusuf dan R. Kusdarwati. 2009. Isolasi dan Identifikasi Bakteri Gram Negatif Pada Luka Ikan Maskoki (Carassius auratus) Akibat Infestasi Ektoparasit Argulus sp. J Ilmiah Perikanan dan kelautan (2)1: 129-134.

Kresnawaty, I., S. Andanawarih., Suharyanto., T. Panji. 2008. Optimization and Purification of IAA Produced by Rhizobium sp. In Latex Serum Media Supplemented with Tryptophan from Chicken Manure. J Balai Penelitian Bioteknologi Perkebunan 76(2): 74-82.

Lay, W. B. 1994. Analisis Mikroba di Laboratorium. PT Raja Grafindo Persada, Jakarta.

Lestari, P., D.N, Susilowati., E. I, Riyanti. 2007. Pengaruh Hormon Asam Indol Asetat yang 
Dihasilkan oleh Azospirillum sp. Terhadap Perkembangan Akar Padi. J Agro Biogen 3(2): 66-71.

Munif A., W. Suryo., Suwarno. 2012. Isolasi Bakteri Endofit Asal Padi Gogo dan Potensinya sebagai Agens Biokontrol dan Pemacu pertumbuhan. $J$ Fitopatologi Indonesia 8(3): 57-64.

Patil, R.S., V. Ghormade., and M. V. Desphande. 2000. Chitinolytic Enzymes Exploration, Enzyme and Microbiol. Technol. J Elsevier Science 26(7): 473-483.

Patten, C. L., \& B. R. Glick. 2002. Role of Pseudomonas putida Indole Acetic Acid in Development of The Host Plant root 68(8): 3795-3801.

Pujiyanto, Sri., E Kusdiyantini., dan M. Hadi. 2008. Isolasi dan Seleksi Bakteri Kitinolitik Isolat Lokal yang Berpotensi untuk Mengendalikan Larva Nyamuk Aedes aegypti L. J Biodiversitas 1(9): 5-8.
Sinta, M. M. 2008. Produksi Indole Acetic Acid (IAA) Oleh Rhizobakteri Bacillus sp. 1 DUCC-BR-K1.7 Pada Medium Nutrient Broth dengan Konsentrasi Triptofan Yang Berbeda. Skripsi. Dept. Biologi Fakultas Matematika Dan Ilmu Pengetahuan Alam. Univ. Diponegoro, Semarang.

Sukmadewi, D. K. T., Suharjono dan S. Antonius. 2015. Uji Potensi Bakteri Penghasil Hormon IAA (Indole Acetic Acid) dari Tanah Rhizosfer Cengkeh (Syzigium aromaticum L.). J Biotropika 2(2): 91-94.

Tarabily, K., A. H. Nassar., K. Sivasithamparam. 2003. Promotion of Plant Growth By An Auxin- Producing Isolate of The Yeast Williopsis Saturnus Endophytic In Maize Roots. The Sixth U. A. E University Research Conference. 